\title{
「トランス・リジョナル」な地域研究 としての「一神教の学際的研究」
} 森 孝一

\section{1.「トランス・リジョナル」な 地域研究として}

地域研究は特定の地域について、さまざまな 方法論を動員して、学際的に研究する学問分野 である。21世紀COEプログラムに採択された地 域研究のほとんどすべてが「学際・総合・新領 域」の分野においての採択であったことは、き わめて自然であると言えよう。

同志社大学のCOEプログラムである「一神教 の学際的研究一文明の共存と安全保障の視点か ら」は、そのタイトルに謳っているように「学 際的研究」であり、採択された分野は「学際・ 総合・新領域」であった。しかし、本COEプロ グラムは純粋な意味での地域研究ではない。研 究対象は特定の地域ではなく、欧米においては 「アブラハムの宗教」(Abarahamic Religions) と呼ばれている、中東生まれの一神教（ユダヤ 教・キリスト教・イスラーム) とその世界であ る。

一神教と只の世界を研究対象とするが、研究 の方法は比較宗教学にとどまらず、キリスト教 神学、イスラーム学、ユダヤ教研究、地域研究、 国際政治学、科学史、比較文明論研究などを動 員する、まさに学際的研究である。地域研究と いうきわめて学際的な研究分野を含むさらに多 様な学問領域と、学際的に協働することをめざ すという意味において、地域研究以上に「新領 域」としての研究であると言えるだろう。
「一神教とその世界」を研究対象とするという ことは、地域研究としては、どの地域を研究領 域とするのか。一神教が関係する地域は世界の ほとんどすべての地域であり、とくにどの地域 を扱うかは、取り扱おうとする事象が世界のど の地域と関連しているかによって決定される。 特定の地域を研究対象とするのではなく、扱お うとする事象がその地域を決定すると考えてい いだろう。本COEプログラムと地域研究の関係 をより明らかにするために、一つのケース・ス タディを紹介しよう。それは、2005年秋から翌 年2月にかけて問題となった「ムハンマドの風 刺画」事件である。

この問題を扱った本COEプログラムの研究成 果として、2007年1月に『E Uとイスラームの 宗教伝統は共存できるか一「ムハンマドの風刺 画」事件の本質』(森 孝一編著、同志社大学一 神教学際研究センター企画、明石書店）を出版 した。本書は2部から構成されている。第1部は 「『ムハンマドの風刺画』事件の概要と各地域か らの反応」であり、これが地域研究にあたる部 分である。しかし、この場合の地域研究は特定 地域の研究ではなく、「トランス・リジョナル」 とも言うべき、地域横断的な研究である。「ムハ ンマドの風刺画」事件が世界の各地域において、 どのように受けとめられ、どのような反応を生 み出したかについての報告である。具体的に目 次に即して、どのような地域を扱ったのかを紹 介しよう。 
第1章「E U（ヨーロッパ連合）一風刺画問 題の背景を探る」は、本COEプログラムの事業 推進担当者の一人であるミッシェル・モール 氏によるデンマーク、オランダ、フランスに おける現地調査の報告である。第2章「デンマ 一ク一氷山に隠された危機」は、事件の発端と なったデンマークにおける、事件の政治的・社 会的・宗教的背景についての分析である。第3章 から第7章までは、「ムハンマドの風刺画」事件 に対するイスラーム世界からの反応を扱ってい る。取り上げた地域、国、組織は、イラン、イ スラーム過激派、エジプト、アラビア湾岸諸国、 東南アジアである。第8章と第9章では再びョー ロッパに戻り、イギリスとドイッにおける状況 を扱い、第10章ではヴァチカン（カトリック教 会）およびプロテスタント諸教派・正教会の連 合組織である世界教会協議会の反応を扱ってい る。第1部の最後である第11章ではイスラエル を取り上げた。この事件の経過の中で、イラン のアフマディネジャド大統領が指摘した「ムハ ンマドの風刺画」事件とホロコーストに対する 欧米世界の二重基準の問題との関係で、イスラ エルの反応を紹介している。イランの新聞社は 「ホロコーストの風刺画」のコンテストを企画 し、表現の自由についての欧米世界の二重基準 を批判した。

第12章から第15章は第2 部「『ムハンマドの 風刺画』事件の分析」である。イスラーム法学、 キリスト教神学、アメリカ宗教研究をはじめと
するいくつかの学問分野からの「ムハンマドの 風刺画」事件についての分析であるが、ここで 詳細に触れることはしない。最後の「補説」は、 「ムハンマドの風刺画」事件に引き続いて起こっ た教皇ベネディクト 16 世によるイスラーム発言 (2006年9月）の背景についての分析である。

このように、本COEプログラムの研究対象は あくまでも一神教と穴の世界である。キリスト 教世界、あるいは「かつての」キリスト教世界 としてのヨーロッパで起こった「ムハンマドの 風刺画」事件は、ヨーロッパの統合理念とは何 か、また、ヨーロッパの世俗的価值の一つであ る「表現の自由」とイスラームに先鋭化される 宗教的信念の尊重との関係はいかなるものであ るべきか、という問題を顕在化させる象徴的な 事件であり、一神教研究が取り組むべき、典型 的な現象の一つであった。それはヨーロッパに おけるイスラーム、あるいはヨーロッパとイス ラームの宗教伝統の関係だけではなく、インタ 一ネットをはじめとするマスメディアの発展の 結果として、「瞬時に」世界各地域のイスラーム 世界の反応を呼び起こす事件となった。

本書の「トランス・リジョナル」な研究を可 能にしたものは、本COEプログラムが事業推進 担当者あるいは共同研究員として、ヨーロッパ およびアメリカのキリスト教、中東地域の各国 および東南アジアのイスラーム、そしてイスラ エル扰よびヨーロッパのユダヤ教を専門領域と する研究者を擁していたことがあげられるだろ 
う。また、過去 4 年間のCOEプログラムの一つ の成果として、世界各地域の研究者とのネット ワークが構築され、世界各地域から本書のため の執筆者として参加していただけたことも、本 書の完成にとって大きな力となった。

\section{COEプログラムと 神学研究科の再編}

本COEプログラムの中核拠点は同志社大学大 学院神学研究科である。神学研究科と共に本 COEプログラムの実質的な事業推進のための機 関として、「同志社大学一神教学際研究センタ 一」が、大学の研究センターの一つとして2003 年に設置された。

本COEプログラムと神学研究科との関係は形 式的なものではない。時系列に従って述べると、 神学研究科の新しい方向性の探究と再編への意 志が先にあり、その後、COEプログラムへの採 択があったのである。

同志社大学神学部と神学研究科は日本に打け る最初の神学研究教育機関であり、その研究教 育の領域はキリスト教神学、とくにプロテスタ ント神学に集中してきた。しかし、2000年ごろ から、時代の要請に応えるための神学研究の新 しい方向性への探求が、教授会レベルで継続的 に行われてきた。2001年9月11日のいわゆる 「同時多発テ口」事件は、新しい神学研究教育の 探求への動きを、強く後押しするものとなった

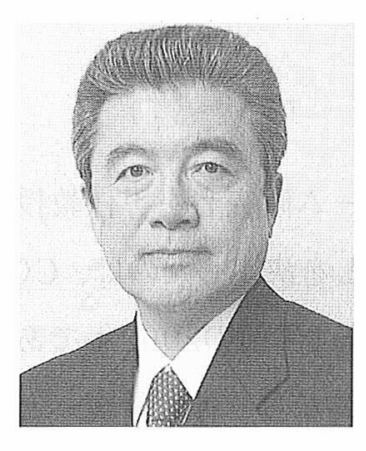

\section{PROFILE}

森 孝一

（もり こういち 1946年生）

同志社大学21世紀COEプログラ

厶「一神教の学際的研究一文明

の共存と安全保障の視点から」

拠点リーダー・同志社大学大学

院神学研究科教授・同志社大学

一神教学際研究センター長

専門: アメリカ宗教史

のは事実である。

世界の各地域において激しさを増している対 立と抗争の多くが一神教世界に打けるものであ り、宗教が主なる原因ではなくても、それぞれ の一神教が詨立と抗争に正当化の根起を与える 役割を担っているという現実を、一神教研究は

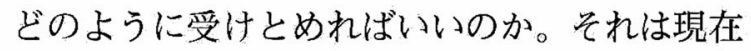
の一神教についての批判的研究への要請であり、 一神教相互の共存と共生をめざす、新たな一神 教神学への模索であったと言えるだうう。

同志社大学大学院神学研究科を、従来のキリ ス卜教神学に特化した宗教研究機関から、ユダ ヤ教、イスラームも含む、中東生まれの三つの 一神教を研究対象とする宗教研究機関に再編す ること。これが神学部・神学研究科が求めた新 しい方向性であった。

神学部・神学研究科の新しい方向性への模索 は、ただユダヤ教やイスラームについての科目 を設置するというとこうに留まらなかった。そ れらの新たな科目を外部の嘱託講師に頼るので はなく、専任教員が担当すること。すなわち、 教授会メンバーの再編なくしては、本質的な変 革はあり得ないと考えられるようになったので ある。 
最初のイスラーム研究者を専任教授として教 授会に迎えることを決定したのは、COEプログ ラムに採択される 1 年前の 2002 年であった。キ リスト教神学研究から一神教研究へという神学 部・神学研究科の再編が開始された直後に、文 部科学省の 21 世紀COEプログラムがスタート し、2003年夏に「一神教の学際的研究一文明の 共存と安全保障の視点から」がCOEプログラム として採択されたのである。

採択された後も、神学部・神学研究科の再編 は着実に進められてきた。本年度（2007年度） における神学部教授会の構成メンバー（專任教 員）は、キリスト教神学研究者11名、イスラー 厶学研究者 4 名、ユダヤ学研究者 2 名であり、イ スラーム学研究者のうち 3 名はイスラーム教徒 (ムスリム) である。神学部・神学研究科の設置 科目のうち、アラビア語、ペルシア語を含むイ スラーム関係科目の科目数は30科目を超えてい る。三つの一神教の研究者は、日常的に生活を ともにし、同じクラスを共同担当し、日常的に 相互に学問的刺激を受けながら、それぞれの神 学研究の再検討を行っている。

教育分野での神学研究科の再編としては、従 来のキリスト教神学の各分野の 4 コース（聖書 学、キリス卜教史、組織神学、実践神学) と並 んで、一神教学際研究コースが設置された。そ のことによって、従来からの教育目的である牧 師をはじめとする「キリスト教のスペシャリス ト」の養成と共に、あらたに「文明の共存のた
めのスペシャリスト」の養成が神学研究科の教 育目的として設定された。

\section{3. 本COEプログラムの現状}

本COEプログラムの開始時から、研究の中心 として、二つの部門研究が設置された。部門研 究 1 は「一神教の再考と文明の対話」、部門研究 2 は「アメリカのグローバル戦略と一神教世界」 である。部門研究 1 は思想・神学、部門研究 2 は外交・安全保障の研究領域において、一神教 とその世界（文明）の共存と安全の実現をめざ すものである。日本においてはとくに、政治学 者はほとんど宗教を考慮しないし、反対に、宗 教学者は外交や安全保障との関係で研究を行う ことがないのが現実である。二つの研究分野の 「有機的な」協働は、実際にはなかなか難しいと ころがあるが、最終年度となる今年度は、す心゙ ての部門研究会を二つの部門の共同研究会とす ることにより、二つの研究分野の間に少しでも 多くのブリッジを架けることをめざしている。

さらに昨年度からは、部門研究 3 「日本宗教 から一神教への提言」を発足させた。日本、と くに京都において一神教研究を行うことを考慮 すると、日本宗教から一神教世界に対して、対 話可能な、そして建設的な提言を発信していく ことが重要であるという判断からである。

本COEとは直接関係はないが、2005年にスタ 一トした「京都・宗教系大学院連合」(Kyoto 
Graduate Union of Religious Studies）は、 京都に打ける日本宗教研究と一神教研究の交流 と対話の場となることが期待されている。参加 大学は、佛教大学、花園大学、高野山大学、大 谷大学、龍谷大学、種智院大学の仏教系大学 院 - 大学と一神教研究の同志社大学神学研究科 であり、2006年度からは単位互換を含む教育に 扣ける交流が始まり、共同研究として「仏教と 一神教」研究会が開始されている。

本COEプログラムは、毎年、国際ワークショ ップを開催してきた。第1回は地域を限定せず 「宗教における戦争と暴力一一神教世界からの応 答」をテーマに開催されたが、第2回以降は、特 定の地域に批ける一神教の課題をテーマとして いる。第2回はアメリカ合衆国、第3回は東アジ ア、第4回はE U（ヨーロッパ）を取り上げてき た。今年度（第5回）は10月に「イスラームと 西洋一アメリカの外交思想を検証する」のテー マで、アメリカの中東政策とその外交思想につ いて、2 日間にわたって議論を交わす予定であ る。キーノート・スピーカーとして、フランシ ス・フクヤマ氏の招聘が決定しておりり、イラン からシーア派の宗教研究者、イラクからスンニ 派の宗教指導者の参加が予定されている。

最後に、海外への研究成果の発信と、海外の 研究機関との学術交流について紹介したい。毎 年開催されている国際ワークショップの報告書、 本COEプログラムの学術雑誌である『一神教学 際研究』(JISMOR) は、日本語、英語、アラビ
ア語の3力国語で、世界各地域の研究機関に送ら れている。本COEプログラムのすべての活動と 研究成果を掲載しているウェブ・サイト （http://www.cismor.jp/）も3カ国語で発信さ れている。

学術交流協定に関しては、イスラエル、シリ ア、ヨルダン、エジプト、マレーシア、アメリ 力合衆国の大学・研究所とすでに締結し、共同 シンポジウムの開催などの共同研究を行ってい る。

本COEプログラムの一神教研究の目的は、共 存・共生、安全・安心の実現という、世界が直 面している緊急の課題であるが、その研究はま さに「新領域」であり、もちろん、すぐに具体 的な成果を伴うようなものではない。しかし、 歴史的・地政学的に、一神教世界間の対立と抗 争の外に位置してきた日本に打ける一神教研究 が、とくにイスラーム世界から注目され、期待 されていることを実感している。 